\title{
Challenges and Problems of Learning Islamic Religious Education in the Digital Era
}

\author{
Yeri Nofrianti ${ }^{1 *}$, Arifmiboy $^{2}$ \\ ${ }^{1}$ Institut Agama Islam Negeri (LAIN) Bukittinggi, Indonesia, email:yerinofrianti368@gmail.com \\ ${ }^{2}$ Institut Agama Islam Negeri (IAIN) Bukittinggi, Indonesia, email: arifmiboy@yahoo.co.id \\ *Corresponding Author
}

\author{
(c) (i) (2) \\ (C)2021 by the authors. Submitted for possible open access publication under the terms and conditions of the Creative Commons \\ Attribution-ShareAlike 4.0 International License-(CC-BY-SA) (https://creativecommons.org/licenses/by-sa/4.0/) \\ doi) DOI : http://dx.doi.org/10.30983/it.v5i1.4375 \\ \begin{tabular}{l|l|l} 
Submission: 27 May 2021 & Revised : 4 July 2021 & Published: 31 July 2021
\end{tabular}
}

\begin{abstract}
This study explains the challenges and solutions to problems that arise related to the presence of a digital based technology world, one of which leads to the world of Islamic education. Islamic religious education must reform and innovate its system. Because if this is not done, then Islamic Religious Education will be left behind, especially in relation to the learning process in the classroom. Currently, the presence of a sophisticated technology based learning model will certainly be a challenge and a separate problem for Islamic Religious Education, especially in the learning process that will be carried out, is Islamic Religious Education able to compete and not be left behind in today's digital era. This issue is certainly quite complicated for all related elements, because situations like this have never happened before. The research method used is Library Research, where the data taken comes from writings and literature that support this research. Preliminary findings show that today PAI must be able to compete and leave conventional ways to reform in accordance with the current situation. PAI is considered necessary to find solutions to the challenges and problems of Islamic Religious Education because this is an important aspect in the world of Islamic education, especially in order to be able to give birth to civilized humans and future leaders in accordance with Islamic teachings.
\end{abstract}

Keywords. Challenges and Problems, Learning Islamic Religious Education, Digital Era

\begin{abstract}
Abstrak
Penelitian ini menjelaskan tentang tantangan dan solusi dari permasalaban yang muncul berkaitan dengan hadirnya dunia tekhnologi berbasis digital, dimana salah satunya mengarah kepada dunia Pendidikan Islam. Pendidikan Agama Islam harus melakukan pembaharuan dan inovasi terhadap systemnya. Karena jika ini tidak dilakukan, maka Pendidikan Agama Islam akan semakin tertinggal, terutama dalam bubungannya dengan proses belajar di kelas. Saat ini hadirnya model pembelajaran berbasis tekhnologi yang canggib tentu akan menjadi tantangan dan problematika tersendiri bagi Pendidikan Agama Islam kbususnya dalam proses pembelajaran yang akan dilakukan, apakah Pendidikan Agama Islam mampu bersaing dan tidak tertinggal dalam era digital hari ini. Persoalan ini tentu cukup pelik dirasakan oleh semua unsur yang terkait, karena situasi dan keadaan seperti ini belum terjadi sebelumnya. Metode penelitian digunakan adalah Library Research, dimana data yang diambil berasal dari tulisan dan literatur yang mendukung penelitian ini. Hasil temuan awal menunjukkean bahwa hari ini PAI harus mampu bersaing dan meninggalkan cara-cara konvensional menuju pembaharuan yang sesuai dengan keadaan saat ini. PAI dianggap perlu mencarikan solusi atas tantangan dan problematika Pendidikan Agama Islam karena hal ini merupakan aspek penting dalam dunia Pendidikan Islam khususnya agar mampu melabirkan manusia beradab dan pemimpin masa depan yang sesuai dengan ajaran Islam.
\end{abstract}

Kata Kunci: Tantangan dan Problematika, Pembelajaran Pendidikan Agama Islam, Era Digital

\section{Background}

The digital era is a condition where humans can freely carry out various d esires, one of which is getting accurate and fast information. Someone who is used to using digital applications will make his world feel very wide because he can find and process the information he wants himself. If we searched for information by using other electronic tools such as newspapers, magazines and newspapers, today this is no longer true and 
even abandoned. Everyone needs to master the world of technology to get the data they want. It will be very easy to use the results of the developing world of technology called the digital era to get knowledge. ${ }^{1}$

The emergence of the digital world today has at least given various impacts in human life. One of the biggest changes felt today as the influence of the digital era and advances in information and communication systems has drastically changed a person's habits and judgment in seeing things. One of these habits and judgments comes from the influence of information technology, especially now that it has brought new changes in the development of the world of education. However, this development has not yet been realized following what is desired because there are still many obstacles and it is necessary to make improvements and innovations. On the other hand, it is still difficult to find quality human potentials to master and engage directly in the competition. So that makes our nation must make a new breakthrough to create a society full of technology. With these emerging problems, the right solution must immediately be given to build the nation's young generation who can compete and be competitive in today's sophisticated digital competition. ${ }^{2}$ Significant changes occur in the order of human life, especially in the world of education in Indonesia. Today, education in Indonesia gives birth to a new formulation towards progress, which is certainly felt by all parties who contribute to it. One that is no less important and interesting can be seen from the students of this digital era. As Prensky said that "the students of today have experienced a very drastic and difficult development compared to the situation in the past". In addition, Prensky stated that "today's students represent that they are students who were born and developed in the digital era. They have even used most of their time to be able to dive into using and become fanatical followers of the advanced features that appear in this digital technology. ${ }^{3}$

This situation is certainly a very proud thing because it shows that we are already in an era of progress full of technological developments towards a new civilization. Advances in technology have been able to solve most of the problems in the line of human life. With this situation, of course, a person no longer always depends on other people for his life. Everyone will be able to get knowledge and information following what is desired and needed in carrying out the wheels of life. Everyone has the same opportunity to extract any information without being limited by circumstances. However, on the other hand, technological advances in this digitalization era will certainly impact everyone's personal life which will be very easily accessible by anyone at any time. For this reason, the best action is not to reject technological progress, but to welcome it with an open attitude and full of preparation. So that we are not run over by every current that comes in the development of today's progress. ${ }^{4}$

However, in fact this change must be watched out for by everyone, especially education controllers in Indonesia. Given that it is not impossible that this digital era can also plunge someone into a bad direction if there is no good control within the person who uses it. Because right now we can no longer stem the currents of digitalization that exist. Moreover, the country which is currently facing various other problems in the field of education that are so complex and sensitive, including expansion in terms of equal distribution of educational
${ }^{1}$ Shulhan Alfinnas, "Arah Baru Pendidikan Islam di Era Digital," Fikrotuna 7, no. 1 (2018): 803-17, https://doi.org/10.32806/jf.v7i1.3186.

2 Sofian Abdulatif, "Dampak Pandemi terhadap Eksistensi Pendidikan di Era Digital" Jurnal Pendidikan Tambusai 5 (2021): 1567-70.
3 Prodi Pendidikan et al., "Evaluasi Kesiapan Lembaga Pendidikan Tinggi Islam dalam Menghadapi Era Digital" Tadibuna 9, no. 1 (2020): 19-33, https://doi.org/10.32832/tadibuna.v9i1.2604.

${ }^{4}$ Wawan Setiawan, Seminar Nasional Pendidikan, "Era Digital dan Tantangannya," 2017, 1-9. 
opportunities for all citizens, increasing the relevance of education and the needs of life, and increasing the level of education. The quality of education, the endless development of culture and national identity, and the annexation of foreign cultures to improve the efficiency and effectiveness of education, are equally important for nurturing the next generation of the baton of national leadership. ${ }^{5}$ The education sector in Indonesia at this time is actually not doing well and is facing extraordinary challenges and requires the cooperation of all of us so that this education can continue to advance with the flow of times that cannot be contained.

The world of education must provide leading-edge information in providing understanding to the nation's young generation so that they can use the sophistication of this digital era as well as possible. All generations of the nation must be equipped to understand the pros and cons of using technology in the current digital era. However, what is provided with this technology provision is not only the young generation of school age, but every family is also given the understanding to be able to pay attention, supervise and assist their children in using technology as well as possible. All parties need to be explained the use of this digital era technology properly so that there are no mistakes in its use and bad consequences for its users. ${ }^{6}$ Education observers can no longer stand idly by in the face of the current state of the nation. The world of education must immediately adapt to the new civilization that is growing. Therefore, the right way to use is to control this digital era correctly and usefully. Furthermore, this ofcourse must be done in the right ways and controlled properly so that it can positively impact the younger generation and our society. On the other hand, there must be a good filter to be given to this nation's generation. So, their development aligns with the ideals and goals of Indonesian education, especially in achieving the goals of Islamic education with good morals based on the instructions that have been conveyed by Allah swt and the Prophets. His. Because basically the content of Islamic learning is based on the instructions of Allah swt and the Messenger of Allah which is a source of strength and sturdiness of Islamic education. God's instructions are an important guide in every human being that must be instilled in all the souls of this nation's young generation for the realization of an education that is not only intellectually intelligent but also spiritually intelligent and in behavior. While the Sunnah is the main foundation after the Qur'an which comes from what has been determined by the Messenger of Allah which can be used as a guide and guidance for his people in living life and in interacting with his fellow creatures.

Therefore, along with the development of this digital era, one of the best filters to be able to form a young generation who is blessed with good deeds following what this nation wants is through learning Islamic education. Religious education aims to form a perfect human being who is closer to Allah swt. Religious education is also expected to provide awareness for students as creatures of God so that they can carry out their life functions as caliphs on this earth. ${ }^{8}$ Islamic education means integrated guidance carried out by Islamic education teachers in providing understanding to students to form good and commendable personalities. Based on this, Islamic education is considered the main point in shaping one's personality towards good morals. So that with Islamic education it is hoped that it can be the best solution for Muslims in welcoming their lives in
5 Abdulatif, "Dampak Pandemi Terhadap Eksistensi Pendidikan di Era Digital”, 15

6 Wawan Setiawan, "Era Digital dan Tantangannya", 6
7 Nurul Ulfatin, "Pendidikan Islam Tadzikrah," Tadzkirah 2 (2008): 107-51.

${ }^{8}$ Abdul Khobir, "Pendidikan Agama Islam di Era Globalisasi," Forum Tarbiyah 7, no. 1 (2009): 1-11. 
the future. ${ }^{9}$ Besides that, Islamic religious education can be understood as a way to teach someone the values contained in the teachings of Islam itself, so that anyone who practices it in life will certainly become good habits and can have a positive impact on his life as a generation of Islam in particular. ${ }^{10}$ Today the position of Islamic education itself continues to progress and shift. Progress that can be seen today, for example in the various approaches taken in the management of learning. Once an educator was the only key informant in the world of education, educators are considered competent people in providing explanations and information to their students. However, today, in the midst of an increasingly advanced era, the situation has changed. The teacher's responsibility is no longer the only explanation of learning, but as a facilitator for students in the sense that today's students contribute more to discover and explore their own knowledge. ${ }^{11}$ However, according to the author's opinion, no matter how sophisticated the development of technology, the roles and responsibilities of educators in the world of education will certainly never be replaced, in the teaching and learning process educators are still required to provide reinforcement and the essence of the learning materials delivered to their students. Educators are the only ones who are considered capable of assessing the truth of a material presented. Besides that, educators are considered people who understand the characteristics and personalities of their students. When problems arise in the learning process, it is educators who know the solutions to these problems.
Other problems that are also challenges and problems arise from the side of developing the quality of education, which is also a challenge in today's digital era. Our future role as educational practitioners will certainly be more difficult if we do not prepare carefully. We need good cooperation for all of us to respond to the current development of the times and challenges in the future. ${ }^{12}$ The emergence of discrepancies from students' behavior who are far from the values and norms contained in Islam. It also comes from the perspective of the quality and quality of education, educational strategies that have not been innovated, materials/curricula that have not been able to answer the demands of today where students are expected to can compete nationally or beyond.

On the other hand, what is no less emotional is the habits shown by the young generation of our nation today which reflect behavior that is no longer following the identity of a civilized and moral nation. The news that we get both from television and other online media is often a frightening specter at this time. Lately, news often appears in the public sphere about the occurrence of murder, rape, robbery and so on, most of the perpetrators, including the nation's young generation who should be the pride of all of us. The decline in the morals of our young generation today is certainly a blow, especially in the world of education, which tends to highlight its presence and existence. ${ }^{13}$ It is certainly in contrast to the direction if we look at education in the past, which was far from the impression of technological progress but could create future reliable, capable, and moral generations. This
9 Herman Suherman, "Problematika dan Tantangan Pembelajaran Pendidikan Agama Islam di Tengah Pandemi Covid-19", Tsamratul Fikri: Jurnal Studi Islam 14, no. 2 (2020): 199-212.

10 Pasmah Chandra, "Problematika, Tantangan dan Peluang Pendidikan Agama Islam di Sekolah dan Perguruan Tinggi di Era Globalisasi” Jurnal Aqhniya 3, no. $1(2020): 123$
11 S Priyatmoko, "Memperkuat Eksistensi Pendidikan Islam di Era 4.0," Ta'lim: Jurnal Studi Pendidikan Islam 1, no. 2 (2018): 1-19.

12 Abdulatif, "Dampak Pandemi Terhadap Eksistensi Pendidikan di Era Digital, ” : 1568

13 Wawan Setiawan, "Era Digital dan Tantangannya.", 1-9 
phenomenon should be an essential lesson for us, especially for education stakeholders nowadays. We know that technology is progressing and should improve the morals of the younger generation, not the other way around. Besides that, there are also many attitudes of our young generation today who tend to be passive and interact less with others as a result of enjoying the games found on online media which are far from educational and even worse, they sometimes don't care about the circumstances around them. ${ }^{14}$

If we look further, of course this situation has eroded some of the nation's character. Such as the loss of moral values, lack of empathy for others, prioritizing personal interests, less concern for the social environment, promiscuity and various other negative impacts on our young generation today, especially in the current digital era. Where it no longer reflects the identity of the nation and the goals of Islamic education, especially those with good character. In fact, if we look at the teachings of Islam as exemplified by the Prophet Muhammad, morality is an important factor in fostering and building a nation. ${ }^{15}$ This is as the hadith of the Prophet Muhammad "Indeed I was sent to perfect the glory of morality." (HR. Ahmad). From this hadith it is clear that the readiness of Islamic education to create a good generation, as exemplified by the Prophet Muhammad. If humans have made the Messenger of Allah as an example in life, then it is impossible to fall into things that are contrary to the teachings of Allah swt (whoever obeys the Apostle, then indeed he has obeyed Allah swt: Qs An-Nisa, 80).
Therefore, this digitalization era should be able to prepare a skilled and knowledgeable Islamic generation through Islamic education itself so that it can create cadres of the nation with character. For this reason, it is necessary to think about the best ways so that this education can continue to run optimally amid the temptation of this increasingly developing and advanced digital age. Indeed, education practitioners only need to work together to create new formulations, especially in Islamic education so that we are not crushed by the times that continue to develop towards the direction of a new civilization.

Previous research by Noor Amiruddin with the title Problematics of Islamic Education Learning in the Digital Era, where the results stated that Islamic education is currently faced with new challenges and needs that have never existed before, so that it is necessary to reform and innovate the education system. If not done, then Islamic education will be left behind and obsolete. ${ }^{16}$ Then in another study conducted by Amirul Bakhri, explaining to us that Islamic education in Madrasas/schools must strive to develop themselves. ${ }^{17}$

Islamic religious education will be at the forefront of this advanced technological competition by creating the right design. Abuddin Nata stated that religious education has a very big role today, namely preparing people with piety and understanding religion well. Thus, religion will have a major influence in living their lives. ${ }^{18}$ Thus it is not impossible that later Islamic education can compete both in the smallest scope to a wider scope. In other words, the world of Islamic religious education is currently being tested for its existence to be

\footnotetext{
14 Wawan Setiawan, "Era Digital dan Tantangannya.", 1-9
15 Farida Asyari, "Tantangan Guru PAI Memasuki Era Revolusi Industri 4.0 dalam Meningkatkan Akhlaq Siswa di SMK Pancasila Kubu Raya Kalimantan Barat," Muslim Heritage 4, no. 2 (2019), https://doi.org/10.21154/muslimheritage.v4i2.1779. Pendidikan Agama Islam di Era Digital," Prosiding Seminar Nasional PAI dengan Pendekatan Multidisipliner, 2019.

17 Amirul Bakhri, "Tantangan Pendidikan Agama Islam di Madrasah Pada Era Globalisasi," Jurnal Madaniyah VIII (2015): 63-86.

18 Nurhayati, "Tantangan dan Peluang Guru PAI Era Globalisasi”, Jurnal Ilmiah Iqra' 7, no. 1 (2018): 3
} 
able to produce capable generations who will advance this nation in the future. We know that Islamic education is based on the teachings of Allah swt and His Messenger. If we adhere to these teachings, we will be safe in life in this world and in the hereafter. So that the position of Islamic religious education is considered the most important, potential and foremost to continue the ideals of the Indonesian nation.

In this study, the researcher uses the library method. The writing uses sources from books and articles related to research or data collected from various literary sources such as books, journals, and others. ${ }^{19}$. Moreover, the approach that researchers use in this study is a phenomenological approach based on views and assumptions. The meaning given by someone greatly determines the process of interpretation. So the view of the researcher itself is a research construct

This research is also descriptive-analytic, where the research wants to explain in detail and analyze the discussion that is the subject of the research. ${ }^{20}$ The data obtained by the researchers directly were in the form of journals and books that explained the challenges and problems of learning Islam in the digital era and related to the subject under study. ${ }^{21}$

The method of collecting data in this study is explained in various representative ways, such as research-related articles and other relevant online media sources. The data analysis technique uses an interactive model from Miles and Huberman, where the steps needed are initial data collection, data reduction, data display, and verification/conclusion. ${ }^{22}$
The content of this paper also comes from secondary data. Secondary sources, namely supporting data in this study may come from previous studies that discuss the same topic. These secondary sources usually contain research conclusions from the main book. The secondary sources used in writing this article come from journals, books or previous studies that describe the challenges and problems of learning Islamic education in the digital era. ${ }^{23}$

\section{PAI Learning Challenges in the Digital Era}

Along with the development of the current era, there will be many challenges in Islamic Education facing learning, especially the digital era that we encounter today. Many problems arise today, especially in the world of education. It also occurs in Islamic education. So, Islamic education has the potential foundation in achieving the goals and ideals of this nation's education. So it is only natural that Islamic religious learning should be pursued as best as possible in its application at the education unit level ${ }^{24}$

We believe that the noble goal of Islamic education is to create an intellectually, emotionally, spiritually and trustworthy, pious, civilized, have good morals young generation. Islamic education wishes a generation harmonious and polite in their lives today and in the future, especially in today's digital era. Islamic education is considered one of the main lessons that must be applied to support the

https://ejournal.uinib.ac.id/jurnal/index.php/naturalsci ence/article/view/1555/1159.

22 Pasmah Chandra, "Problematika, Tantangan

"Aspek Afektif dalam Pembelajaran Daring Bahasa Arab Berdasarkan KMA 183 Tahun 2019" Muhadasah:Jurnal Pendidikan Bahasa Arab 2, no. 2 (2020): 206-24.

20 Mukodi, "Conseptual Teenager Offer Corruption Watch in The Millenial Era," Jurnal Al-Qalam 25, no. 1 (2019): 187-200.

21 Milya Sari and Asmendri, "Penelitian Kepustakaan (Library Research) dalam Penelitian Pendidikan IPA," Natural Science 2, no. 1 (2018): 15, dan Peluang Pendidikan Agama Islam di Sekolah dan

Perguruan Tinggi di Era Globalisasi”, 126

23 Fajri, Karima Nabila, "Proses Pengembangan Kurikulum" Islamika 1, no. 2 (1994): 35-48

24 Pasmah Chandra, "Problematika, Tantangan dan Peluang Pendidikan Agama Islam di Sekolah dan Perguruan Tinggi di Era Globalisasi.”, 124-136 
ideals of a noble nation's education. ${ }^{25}$ Zakiyah Darajat, in his book, said that Islamic education is the way needed to provide understanding to children so that they can practice the essence of Islamic teachings itself. Where after practicing, it will certainly become a habit for children in their lives. The materials taught are important points that form the basis of the guidance in life. The material in Islamic education wishes the student to understand and try to guide life and become a supporter of life both in worship, muamalah, and others. ${ }^{26}$

However, on the other hand, the challenges of education today also arise from the perspective of the quality and quality of education, educational strategies, materials/curriculum that are currently required to be able to create human resources that can compete in the digital era. This is in line with the opinion of Anik Gufron quoted by Malik Fajar, saying that "without efforts to adapt the curriculum, madrasa schools or other Islamic educational institutions will find it difficult to develop into excellent schools. ${ }^{27}$ If we examine further, our role as teachers today finds a point the most difficult state that was never imagined, because today's teachers are required to be ready and able to carry out and carry out their roles as educational practitioners. Educators must improve their ability to mix and present the material well, following what is desired in today's era.

Besides that, teachers are also required to have the ability to master the sophisticated digital world in supporting the learning they provide. Not to mention the other demands that are being weighed against teachers today. This condition finally makes the condition of teachers who complain and are tired of today's technology so that not a few still choose conventional ways. $^{28}$

\section{PAI Learning Problems in the Digital Era}

In today's digital conditions, we are increasingly aware that Islamic education is faced with various problems that must be faced together. It is due to the following problems:

1. Islamic education learning activities faced by teachers and students in this digital era rely more on technology, while human resource capabilities are insufficient. In fact, if studied more deeply, there is an integration of religious knowledge and general knowledge in Islamic education.

2. In the learning process, the current lack of effectiveness in teaching and learning. This is due to an inadequate understanding of the use of technology in delivering learning. The core of learning is often neglected. Some PAI teachers still use the traditional way of teaching and think that using technology will only make things complex. The teacher think that they need to learn new things. ${ }^{29}$

3. Today's young generation is more inclined to follow foreign cultures due to advancing technology rather than studying domestic culture or cultures full of Islamic teachings. If this situation continues, we will certainly remain backward in the future.

4. Insufficient advice and infrastructure to support the learning process of Islamic religious education. Whereas without educational facilities and infrastructure, the educational process will experience obstacles. Therefore, facilities and infrastructure must be managed properly so
25 Meity Wildanun Nasution and Ima Fitmawati, Efektivitas Multi Metode Pembelajaran PAI Yang Berpusat Pada Siswa (Jakarta: CV. Amerta Media 2020), 3-404

26 Pasmah Chandra, "Problematika, Tantangan dan Peluang Pendidikan Agama Islam di Sekolah dan Perguruan Tinggi di Era Globalisasi.", 124-136

${ }^{27}$ Bakhri, "Tantangan Pendidikan Agama Islam di Madrasah pada Era Globalisasi.”, 63-86
28 Anggun Wulan Fajriana and Mauli Anjaninur Aliyah, "Tantangan Guru dalam Meningkatan Mutu Pendidikan Agama Islam di Era Melenial," Nazhruna: Jurnal Pendidikan Islam 2, no. 2 (2019): 246-65, https://doi.org/10.31538/nzh.v2i2.324.

29 Agus Ali, "Manajemen Guru PAI dalam Menghadapi Tantangan Revolusi di Era 4 .0", Mumtazam: Jurnal Manajemen Pendidikan Islam 02, no. 1 (2021): 27-40. 
that they can develop dynamically and in accordance with the needs and demands of the times. ${ }^{30}$

In addition to the problems described above, other problems arise, especially in today's digital era by utilizing increasingly sophisticated technology. However, what is seen is more moral decline in students, moral dryness, bad behavior and the emergence of deviant social behaviors. With the existence of this digital world, our behavior should be more mature in a better direction, not on the contrary, it causes a lot of negative things. This condition seems to be caused by a person's lack of understanding and knowledge of how important it is to prepare for the demands of this era. If not, then it is precisely the negative impact that will often be seen. This problem, of course, must make education practitioners, especially Islamic Religious Education teachers, continue to make updates and approaches to students, so that they will listen to what message we will convey to them, so that they can minimize negative impacts that may easily occur. So that students feel they have a model that deserves to be worshiped and feel not alienated. ${ }^{31}$

Another problem is that they have not mastered technology well, so that what often appears is the negative impact compared to the positive impact. Lack of competence to master technological advances so that it affects any information needed. This condition results in our young generation's lack of competence and quality, resulting in social behaviors that deviate from what we want, such as the news that often happens today. ${ }^{32}$ No less important challenges faced in PAI learning in the digital era include the lack of dynamic social relationships between teachers and students and the changing responsibilities of teachers being replaced by digital technology. The fading of students' religious attitudes and lack of respect for teachers as knowledge providers, then began to fade religious values in students, less able educators to be role models for their students so that students lose good role models on the side of their lives, loss of support for finding good information and appropriate in understanding a science in the era of technology. ${ }^{33}$ The position of Islamic religious education teachers is considered the main spearhead in answering the problems of today's development so that they can unite existing learning based on content and teachings of values in Islam.

The challenges and problems above must of course need a proper solution, so that our education, especially Islamic education, can continue to develop to meet the needs of the times. Thus, as education practitioners, especially Islamic education, they must be able to find the right and best solutions for the advancement of Islamic education in the future so that they do not experience much lag, especially in producing a generation of Islam that is following the teachings of Allah SWT and His Messenger. This situation will certainly run optimally if it gets full support from all Indonesian people who must unite the goals for the improvement of the nation's young generation in the future. However, if this situation is only realized by one party, of course, the desired expectations will be difficult to realize.
30 Mona Novita, "Sarana Prasarana Yang Baik Menjadi Bagian Ujung Tombak Keberhasilan Lembaga Pendidikan, Sekolah Tinggi Agama Islam," Nur El-Islam 4, no. 2 (2017): 97-129.

31 Sastriani, Dinamika Pembelajaran PAI di Era Digital (Studi di MTsN Wawotobi), Kabupaten Konawe)Shautut Tarbiyah, "Shautut Tarbiyah, Ed. Ke-38 Th. XXIV, Mei 2018,” 2018, 1-18. 


\section{Solutions to face the challenges and problems of PAI learning in the digital era}

In order to overcome the challenges and problems that can arise in this digital era of educational learning, then in fact there are steps that must be taken in dealing with this turmoil in Islamic religious education. Nuryadin stated that appropriate solutions must be given to this problem, such as developing and improving the quality of education implementers, in this case teachers, students and the entire existing educational environment, increasing digitalbased learning support facilities, and creating various interesting approaches in the learning process by continue to put technology as the main idea. ${ }^{34}$ It is impossible for us who live in a technology-based digital age, but we are not able to run it.

1. Provide understanding to human resources, in this case are people who are involved in Islamic education that it is important to master current technology for the realization of quality education. Because the better the quality of teachers (human resources) in education will have a good impact on the achievement and quality of students, of course what is expected is not only to increase in terms of humans but also to increase in terms of quantity and results.

2. Improve the means of supporting digitalbased learning which is certainly a must as an effort and reaction to the advancement of the times. Of course, this is supported by qualified digital facilities. So making improvements to digital and technologybased learning facilities will be able to answer every existing problem.

3. Creating various interesting approaches in the learning process while still prioritizing technology as the main idea. Such as

${ }^{34}$ Amirudin, "Problematika Pembelajaran Pendidikan Agama Islam di Era Digital.", 188

35 Nur Afni Lubis and Imelda Wahyuni, "Peran Teknologi dalam Pembelajaran Pendidikan Agama Islam di Tengah Pandemi Covid-19," An-Nuba 1, no. 1 (2021): 19-24, https://doi.org/10.24036/annuha.v1i1.3. utilizing the internet and other learning support facilities that are loaded with technology so that they can support learning outcomes. The interaction process will occur optimally if the means chosen are appropriate and maximal. Good interactions in digital learning and students' self-confidence will have a positive impact on learning outcomes. ${ }^{35}$

4. The application of applying learning approaches and theories that are in accordance with the conditions of students in the digital era will greatly help the mental readiness of our students to gain an understanding of the material in learning. Even when learning activities, students still collaborate with the importance of the existence of technology.

Likewise, when learning is carried out directly with students, where teachers continue to make innovations that are in accordance with today's developments so that students do not get bored easily with the teacher's teaching style, which is homogeneous but full of renewal. Using contemporary ways in the learning process where methods, approaches, and means support the learning process, the way the teacher conveys will certainly affect students' interest and desire to learn. Especially students in today's millennial era who spend part of their lives making friends with technology as a lifestyle. $^{36}$

Teachers need to implement new ways in the learning process that are considered to be able to dredge the abilities of current students. In addition, educational programs must be renewed, rebuilt, or modernized to fulfill the expectations and functions assigned to them. ${ }^{37}$ Teachers must metamorphose following rapid technological developments so that they are

36 Zainal Arifin, "Problematika Pendidikan Agama Islam di Era Digital," Prosiding Nasional 3 (2020): 115-26.

${ }^{37}$ Nur Hidayat, "Peran dan Tantangan Pendidikan Agama Islam di Era Global," El-Tarbawi 8, no. 2 (2015): 131-45, https://doi.org/10.20885/tarbawi.vol8.iss2.art2. 
expected to balance the living habits of their students in this revolutionary era. The application of digital-based media is certainly expected to improve the quality and quantity of education, especially Islamic education today, which is often seen as classical in the midst of the progress of the times.

On the other hand, as stated by Lismanda, teachers must be able to be good role models for the realization of the morals of the nation's children who are polite and have commendable character. Education must make a transformation, Islamic education stakeholders must make changes to the face and content of the curriculum according to the demands of the times and a bulwark against moral decadence. ${ }^{38}$ Thus, it will be able to create a young generation that is following the objectives of education, especially Islamic education, where the expected generation is intellectually intelligent, good in behavior and has expertise that can be proud of in life. ${ }^{39}$

In addition to the things described above, other solutions in dealing with existing challenges and problems, especially in PAI learning are the need to carry out various policies including:

1. Harmony between the application of learning designs and this government decision to positively impact students' intellectual, social, and psychomotor abilities or skills.

2. Whether or not practitioners of Islamic education are ready to process data and provide information related to the use of technology which will determine the realization of the current quality of education, one of the fundamental things in order to get out of the challenges and problems faced by practitioners of Islamic

38 Abdul Hakim bin Abdullah, "Pendidikan Islam dalam Era Revolusi Industri 4.0," Tamaddun 21, no. 1 (2020): https://doi.org/10.30587/tamaddun.v21i1.1384. education is to be able to use technology well. However, in reality today, it is far from what is desired. Based on research conducted, it informs us that only $37.85 \%$ of educators in Indonesia can apply digital systems to support their learning process and $65.05 \%$ of educators have not been able to use digital technology properly. ${ }^{40}$

The explanation above informs us that there is still much that needs to be done to improve in realizing advanced education according to the needs of today's digital age. In addition, teachers are also required to continue to innovate in packaging learning as attractive as possible, which is in line with students' understanding.

\section{Conclusion}

Based on the explanation of this paper, the author can conclude that in today's digital era there are various kinds of challenges and problems in learning Islamic religious education. First, the challenge of learning PAI in this digital era is how PAI can still create a young generation of Muslims who have good morals and are technologically capable, but do not abandon Islamic values in this regard. Of course this applies to all practitioners of Islamic education in particular.

Second, the problem with PAI learning in this digital era is that there are not enough human resources to master and understand technology, whereas in Islam there is actually an integration in religious and general knowledge. So this causes learning to be ineffective because they do not master the existence of technology that is in accordance with the progress of the current digital age. Besides that, another problem in PAI learning is where we see today that our young Muslim generation is more interested in studying foreign cultures that are

39 Devi Wahyu Ertanti Fella Zulfa Zaein, Mohammad Afifulloh, "Vicratina: Jurnal Pendidikan Islam 5, no. 1 (2020): $1-5$.

${ }^{40}$ Nasution and Fitmawati, Efektivitas Multi Metode Pembelajaran PAI Yang Berpusat Pada Siswa, 3-404. 
not in accordance with Islamic values. Even more extreme without integrating with Islamic values even far from what already exists in our religion. Then there are still limited supporting facilities and infrastructure in PAI learning in this digital era.

Third, the solution that can be done, of course, must be the cooperation of all of us to be able to create a younger generation of Muslims who are in accordance with the development of this digital era without leaving Islamic values in their lives. So that what the ideals of Islamic education in particular can be achieved well. Besides that, it is still trying to make reforms in making policies to prepare this nation's education, so that it can print this nation's young generation who are cognitively intelligent, affectively and psychomotor.

We all have high hopes to make it happen together. If that happens, then maybe we can repeat the glory of Islamic education in the past. In this digital era, Islamic education is a hope for all of us to make significant progress in responding to the challenges of life by reflecting our true identity based on the teachings of Allah swt and His Messenger, both in the present and in the future. This hope can be successful if all relevant parties can carry out their functions properly, then are ready to make changes in carrying out the learning process according to the needs of the times in the current digital era.

By implementing these solutions and changes, we believe that Islamic Education may compete and not be left behind amid an increasingly sophisticated era and full of today's technology. In hoping that there will be a new direction of the education system, not only making the children competent but qualified and capable in carrying out religion and the best behavior.

\section{References}

Abdulatif, Sofian. "Dampak Pandemi Terhadap Eksistensi Pendidikan di Era Digital", Jurnal Pendidikan Tambusai 5 (2021): 1567 -
70.

Abdullah, Abdul Hakim bin. "Pendidikan Islam dalam Era Revolusi Industri 4.0." Tamaddun 21, no. 1 (2020): 127. https://doi.org/10.30587/tamaddun.v21i 1.1384

Alfinnas, Shulhan. "Arah Baru Pendidikan Islam di Era Digital." Fikrotuna 7, no. 1 (2018): $803-17$. https://doi.org/10.32806/jf.v7i1.3186.

Ali, Agus. "Manajemen Guru PAI dalam Menghadapi Tantangan Revolusi di Era 4 . 0, Mumtazam: Jurnal Manajemen Pendidikan Islam 02, no. 1 (2021): 27-40

Amirudin, Noor. "Problematika Pembelajaran Pendidikan Agama Islam di Era Digital." Prosiding Seminar Nasional PAI dengan Pendekatan Multidisipliner, 2019.

Arifin, Zainal. "Problematika Pendidikan Agama Islam di Era Digital." Prosiding Nasional 3 (2020): 115-26.

Asyari, Farida. "Tantangan Guru PAI Memasuki Era Revolusi Industri 4.0 dalam Meningkatkan Akhlaq Siswa di Smk Pancasila Kubu Raya Kalimantan Barat.” Muslim Heritage 4, no. 2 (2019). https://doi.org/10.21154/muslimheritag e.v4i2.1779.

Bakhri, Amirul. "Tantangan Pendidikan Agama Islam di Madrasah pada Era Globalisasi." Jurnal Madaniyah VIII (2015): 63-86.

Chandra Pasmah, "Problematika, Tantangan dan Peluang Pendidikan Agama Islam di Sekolah dan Perguruan Tinggi di Era Globalisasi” Jurnal Agbniya 3, no. 1 (2020): 126.

Fajri, Karima Nabila, "Proses Pengembangan Kurikulum” Islamika 1, no. 2 (1994): 3548.

Fajriana, Anggun Wulan, and Mauli Anjaninur Aliyah. "Tantangan Guru dalam Meningkatan Mutu Pendidikan Agama Islam di Era Melenial." Nazhruna: Jurnal Pendidikan Islam 2, no. 2 (2019): 246-65. https://doi.org/10.31538/nzh.v2i2.324.

Fella Zulfa Zaein, Mohammad Afifulloh, Devi Wahyu Ertanti. "Vicratina: Jurnal 
Pendidikan Islam 5, no. 1 (2020): 1-5.

Hidayat, Nur. "Peran dan Tantangan Pendidikan Agama Islam di Era Global." El-Tarbawi 8, no. 2 (2015): 131-45. https://doi.org/10.20885/tarbawi.vol8.is s2.art2.

Ifadah, Luluk, and Sigit Tri Utomo. "Strategi Pembelajaran Pendidikan Agama Islam dalam Menghadapi Tantangan Era Revolusi," Jurnal Kajian Pendidikan Islam dan Studi Islam, Vol 2 (2) 2019, 51-62.

Iskandar Tsani, Rofik Efendi \& Sufirmansyah "Evaluasi Kesiapan Lembaga Pendidikan Tinggi Islam dalam Menghadapi Era Digital", Tadibuna 9, no. 1 (2020): 19-33. https://doi.org/10.32832/tadibuna.v9i1. 2604.

Jundi, Muhammad, and Muhammad Dalle. "Aspek Afektif Dalam Pembelajaran Daring Bahasa Arab Berdasarkan Kma 183 Tahun 2019", Mubadasab:Jurnal Pendidikan Bahasa Arab 2, no. 2 (2020): 206-24.

Khobir, Abdul. "Pendidikan Agama Islam di Era Globalisasi." Forum Tarbiyah 7, no. 1 (2009): 1-11.

Lubis, Nur Afni, and Imelda Wahyuni. "Peran Teknologi dalam Pembelajaran Pendidikan Agama Islam di Tengah Pandemi Covid-19." An-Nuba 1, no. 1 (2021): $19-24$. https://doi.org/10.24036/annuha.v1i1.3.

Mukodi, "Conseptual Teenager Offer Corruption Watch In The Millenial Era," Jurnal Al-Qalam 25, no. 1 (2019): 187200.,".

Nata, Abuddin (2018). "Pendidikan Islam di Era Milenial," Jurnal Pendidikan Islam,
Conciencia, Vol 18 (1) : 10-28 .

Nasution, Meity Wildanun, and Ima Fitmawati. Efektivitas Multi Metode Pembelajaran PAI Yang Berpusat Pada Siswa, (Jakarta: CV. Amerta Media 2020).

Nurhayati, Tantangan dan Peluang Guru Pendidikan Agama Islam di Era Globalisasi), Institut Agama Islam Negeri Manado Open Journal Systems ”.

Novita, Mona. "Sarana Prasarana Yang Baik Menjadi Bagian Ujung Tombak Keberhasilan Lembaga Pendidikan, Sekolah Tinggi Agama Islam." Nur ElIslam 4, no. 2 (2017): 97-129.

Priyatmoko, S. "Memperkuat Eksistensi pendidikan Islamdi Era 4.0." Ta'lim: Jurnal Studi Pendidikan Islam 1, no. 2 (2018): 1-19.

Sari, Milya, and Asmendri. "Penelitian Kepustakaan (Library Research) dalam Penelitian Pendidikan IPA." Natural Science 2, no. 1 (2018): 15. https://ejournal.uinib.ac.id/jurnal/index. $\mathrm{php} /$ naturalscience/article/view/1555/1 159.

Sastriani, "Dinamika Pembelajaran PAI Era Digital (Studi di MTsN Wawotobi, Kabupaten Koname)". "Shautut Tarbiyah 38, no 24 (2018): 1-18.

Setiawan Wawan, "Era Digital Dan Tantangannya," Seminar Nasional Pendidikan 2017, 1-9.

Suherman, Herman. "Problematika Dan Tantangan Pembelajaran Pendidikan Agama Islam Di Tengah Pandemi Covid19", Tsamratul Fikri: Jurnal Studi Islam 14, no. 2 (2020): 199-212.

Ulfatin, Nurul. "Pendidikan Islam Tadzikrah." Tadzkirah 2 (2008): 107-51. 